This item was submitted to Loughborough's Research Repository by the author.

Items in Figshare are protected by copyright, with all rights reserved, unless otherwise indicated.

\title{
Palestinians in diaspora, empowerment and informal political space
}

PLEASE CITE THE PUBLISHED VERSION

http://www.sciencedirect.com/science/article/pii/S0962629807000911

\section{PUBLISHER}

(c) Elsevier

VERSION

AM (Accepted Manuscript)

LICENCE

CC BY-NC-ND 4.0

REPOSITORY RECORD

Mavroudi, Elizabeth. 2019. "Palestinians in Diaspora, Empowerment and Informal Political Space". figshare. https://hdl.handle.net/2134/8831. 
This item was submitted to Loughborough's Institutional Repository (https://dspace.lboro.ac.uk/) by the author and is made available under the following Creative Commons Licence conditions.

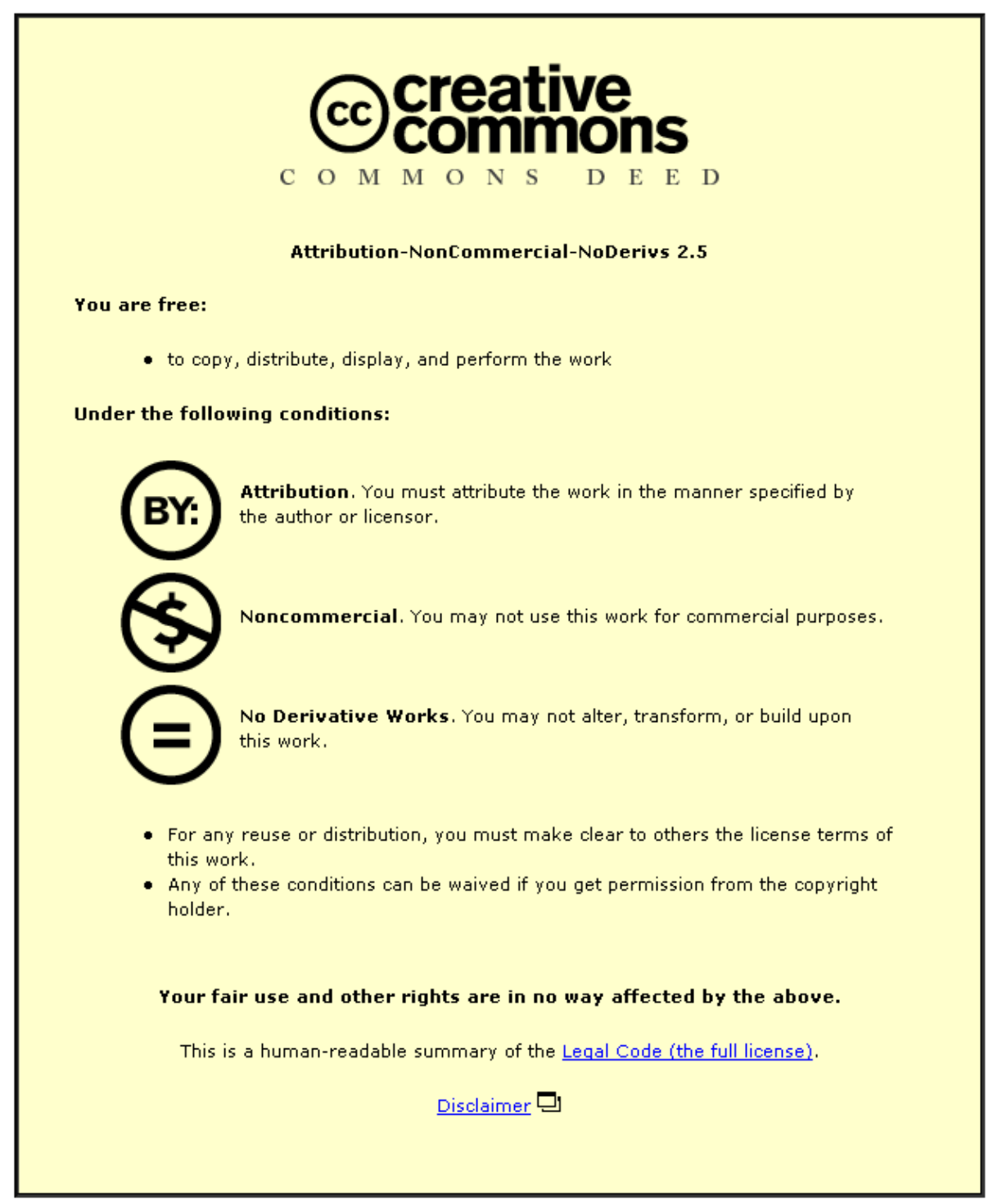

For the full text of this licence, please go to: http://creativecommons.org/licenses/by-nc-nd/2.5/ 


\title{
Palestinians in diaspora, empowerment and informal political space
}

\begin{abstract}
This paper uses empirical research on Palestinians in diaspora in Athens, Greece to add to debates on the nature of diasporic/transnational homeland-orientated politics in relation to identity. It highlights that such politics may be more limited for those who are noncitizens, despite that fact that they may be involved in diasporic political spaces that are informal in nature. It contributes to such debates by examining feelings of empowerment, inclusion and political change within such informal diasporic political spaces. Using the examples of demonstrations and the Parikia (or community house), the paper argues that informal political space can be both empowering and positive as well as disillusioning and negative for Palestinians in diaspora.
\end{abstract}

Keywords: Homeland-Orientated Politics; Empowerment; Informal Political Spaces; Identities; Palestinians in diaspora, Greece.

\section{Introduction}

Within the social sciences, there has been a great deal of research on transnational migrant and diasporic politics in host country and homeland contexts, which is often concerned with identity politics, political participation, and advocacy networks. ${ }^{1}$ The changing nature of the state, identities and citizenship as a result of globalisation, migration and increasing cross-border connections has also been well-documented ${ }^{2}$ leading to differing views on the contemporary role and demise of the state (see, for example, Soysal 1998; Tambini, 2001; Geddes 2001) and the ability of non-citizens to acquire certain rights (for example, see Varsanyi 2005).

The state and the citizenship it bestows on its citizens are often seen as necessary for effective political participation (see, for example, Arendt (1973, cited in Benhabib 2004: 47-61) and feelings of empowerment. This can leave non-citizens or those with ambiguous relations to the state feeling excluded, marginalised and unable to participate (for example, see Kofman 1995). The state remains an important provider of rights and the container of and vehicle for territorialised democracy, despite the increase in political

\footnotetext{
${ }^{1}$ For example, see Smith and Bakker (2005); Carter (2005); Nagel and Staeheli (2004); Liebowitz, (2002); Adamson (2002); Staudt (2002); Al Ali (2002); Al-Ali et al 2001; Cunningham, (2001); Glick Schiller and Fouron, (2001); Itsigsohn (1999); Guarnizo and Smith (1998), Danese (1998); Basch et al (1994).

${ }^{2}$ For example, see Croucher (2004); Benhabib (2004); Castles and Davidson (2000); Ong (1998); Marden, (1997).
} 
transnationalism and diasporic homeland-orientated politics. As Itzigsohn (2000: 1147) reminds us: "political transnationalism ...does not constitute a challenge to the structures of power and the social hierarchies that existed before". In the process, therefore, it is important to counteract the over emphasis of "the success-stories of diaspora politics and the overlapping study of migrants' transnational political practices" (Østergaard-Nielsen 2003: 684), particularly in relation to non-citizens. This paper attempts to counteract such an emphasis by focusing on the role of informal political space in such processes and whether Palestinians in diaspora feel empowered (or not) by their involvement in such spaces.

Political geography has a key role to play in this, enabling the careful exploration of the complex but dynamic spaces and networks involved in such political activities and power relations as a result of globalisation, migration and cross-border connections (see Flint 2000; McEwan 2004; Mitchell 1997). In particular, geographical analyses are well placed to examine the grounded everyday practices and spatial relations that are part of cross-border politics and the "political implications of [such] complex, untidy, differentiated and ambiguous local stories" (Nash 2002: 228). Within this, there must also be a "recognition of the perpetual need to create, conserve and re-create political spaces" (Keith and Pile 1993: 37). As Flint (2002: 391) points out: "political geographers have placed the contested nature of defining political spaces, through both words and action, at the heart of geographical thought".

Geographical research is well placed to uncover and explore in detail the political spaces that have been opened up for non-state actors as they interact across national borders (Marden, 1997: 47). It may also be able to shed light on the extent to which the state still plays a role in political participation and feelings of empowerment despite cross-border connections. As Marden (1997, citing the work of Lipschutz, 1992) stresses, it is necessary to examine whether global processes and the cross-border political spaces in which non-state actors are involved are actually empowering. Research into the new and emerging informal political spaces in which people have the potential to feel empowered, may help further our understanding of how politics/politicisation is negotiated by migrants/those in diaspora who are non-citizens or who have ambiguous relations to the state in relation to identity but also (the lack of) citizenship and the state. 
This paper aims to contribute to such debates on migrant and diasporic homelandorientated politics by focusing on Palestinians in diaspora in Athens and their involvement in specific diasporic political spaces in which they negotiate their identities, feelings of inclusion and advocate the Palestinian cause, as non-citizens. After outlining the theoretical framework and providing contextual information on the Palestinian diaspora, it then goes on to focus on two informal diasporic political spaces: demonstrations and the Parikia.

\section{Diasporic political spaces}

Diasporas can be seen as a form of transnational community with symbolic, but not necessarily concrete, ties to the homeland (Faist 2000). Tölölyan (1991: 4) also notes that "diasporas are the exemplary communities of the transnational moment". Transnationalism forms a useful general framework for this paper as it highlights that those who move still have sustained cultural, social, economic and political ties to their country/homeland of origin (see, for example, Basch et al. 1994; Guarnizo and Smith 1998). Although this paper draws on literature on diasporas and transnationalism, the notion of a diasporic space is used throughout. This highlights that Palestinians are a diasporic group with a fixation on and transnational/cross-border connections to a homeland that may be more symbolic than material and whose physical involvement in homeland politics may be limited because there is no formal Palestinian state.

It is within diasporic spaces that those in diaspora, such as the Palestinians in Athens, engage in homeland-orientated politics, which denotes the practice of supporting or opposing homeland political regimes and, as part of this, 'diaspora politics' describes the political actions of those who are not able to directly participate in the political regime of the homeland (see Østergaard-Nielsen 2001). It is important to research this process of involvement in diasporic homeland or transnational politics because:

"these transnational political practices are not...a passing phenomenon...for a complex set of reasons including the intensification of transnational economic, social and political links across borders, it is becoming increasingly obvious that 
migrants and refugees do not necessarily lose interest in the political affairs of their homeland the longer they stay abroad" (Østergaard-Nielsen 2003: 684).

As a framework for understanding the diasporic political spaces in which Palestinians in Athens are involved, it is useful to note a definition of 'diaspora space' (Brah 1996: 180), which is where "economic, cultural and political effects of crossing/transgressing different 'borders' are experienced... where belonging and otherness is appropriated and contested."

Like diasporic identities, diasporic spaces are often seen as being able to transgress borders, bringing different countries or locations together in ways that may be empowering for those in diaspora, allowing them to potentially engage in homeland orientated political activities. Such spaces, as Staeheli et al. (2002: 996), argue span "two locales - the places of origin and destination" (citing Gilroy 1993 and Laguerre 1998). For those in diaspora, 'here' and 'there', past and present may come together uneasily and ambiguously as both exist within their lives simultaneously. As Soysal (2000: 2) notes: "diaspora is a past invented for the present, and perpetually laboured into shapes and meanings consistent with the present". The spaces those in diaspora create are a reflection of this 'in-between-ness' of past and present and of 'here' and 'there'. Diasporic spaces within the country of residence needs to be placed within this tension between constructing unities and dealing with disunities as well as a need to advocate a cause 'here' that is inevitably linked to the homeland 'there'. Homeland-orientated or diasporic politics can, therefore, be seen as the merging of collective imaginings of belonging 'there' to the daily realities of living and being politicised 'here' within political spaces.

It is within diasporic political spaces where collective feelings of belonging, representation and politicisation are defined and debated and where perceptions of empowerment, hope and agency may potentially arise as the focus is on constructions and use of such space in relation to identity. For those in diaspora with a cause to advocate, it is potentially through such spaces that negotiations of unity within diversity can occur and the following questions may begin to be (partially) answered: "Where do we want to be, and how do we want to get there? What kind of political spaces are there to be 
occupied? And who is this 'we' anyway?" (Keith and Pile 1993: 37). This highlights the notion of collective identities within political spaces as a starting point for the creation of change and social justice.

The symbolic importance of diasporic spaces is important, as it is within and a result of such spaces that powerful senses of 'shared consciousness', persecution and suffering may be articulated. Those with a cause based on perceptions of marginalisation, oppression, injustice and so forth may be drawn to the creation of and involvement in political spaces that allow them to advocate and have a political voice in order to try and deal with their grievances. In France, for example, "immigrant communities have attempted to carve out new political spaces that might be effective in addressing their needs" (Staeheli et al 2002: 996). As Adamson (2002: 156) also points out:

"members of transnational communities can use the political space of the transnational community as a site for the mobilization of identities, discourses and narratives that either challenge or reinforce the official hegemonic discourse of the home state regime...[they] may work for political change ....in order to raise international awareness, thereby increasing pressures for political change in the home state".

Although idealistic, it is tempting to conceptualise informal political spaces as "spaces in which people come together to discuss, listen, and debate political ideas" (Staeheli et al. 2002: 993). This points to the value of political spaces in which otherwise fragmented groups of people may come together at particular points and times. When a group of people are not demanding recognition for political participation within national politics but are engaged in advocating homeland orientated issues, the notion of such a political space becomes useful as an arena for informal discussion, mutual understanding and advocacy. Informal politicised actions may be similar to what Tarrow (1998) has called 'contentious politics', used by people who "lack regular access to institutions". Such increasingly transnational 'contentious collective action' can take the form of political actions such as demonstrations and social movements which those who are involved utilize in order to raise awareness and create change. However, this paper 
problematises such idealised conceptions of informal political space by its focus on notions of empowerment within political spaces.

Political spaces in which people come together are integral to notions of political change and empowerment, which involves:

moving out of constrained places and isolated spaces, widening the scope for action and multiplying potential sites for engagement, and about growing in an organic, self-realizing way - in confidence, in capacity, in wellbeing. (Cornwall 2002: 2)

Cornwall appears to stress that empowerment can only occur if a person is aware of the positive aspects of their political actions and that it is more likely to take place within spaces that are more visible and inclusive. Therefore, the extent to which Palestinians in Athens feel the diasporic spaces they are involved in are politically useful, inclusive or exclusive is important. Cornwall's views also appear to mirror Massey's (1999) plea for spaces to be perceived and constructed as multidimensional, interrelated and open-ended; the result of dynamic, inter-related processes and practices; in the process, "space...is always being made" (Massey 1999: 283).

This has important implications for theoretical understandings of diasporic political spaces (and identities) as bounded, unbounded, continuously dislocated and disrupted. Theoretically, the fact that Palestinian political spaces and identities in Athens are diasporic and dependant on cross-border connections may help 'open up' such spaces and allow those involved to feel more empowered as a result because they are able to draw on as many (cross-border) resources as possible. Such political spaces and identities cannot be seen in isolation to such cross-border relations. As Adamson (2002: 157) argues, "migration-based communities increasingly define themselves and articulate political identities that are formed within a transnational and global, as opposed to a local or national context". Therefore, it may be unsurprising that Itzigsohn (2000: 1146) claims that "transnational politics have opened spaces for participation of previously marginalized groups" and that "we are witnessing the emergence of new forms of political action and citizenship that transcend the territorial and political boundaries of states" (ibid.: 1127). This may be easier for those with formal citizenship status and with 
the ability to participate in homeland and host country politics. For those who are not citizens and who are not able to physically do so, involvement in political activities within such spaces may be more limited and not necessarily empowering, because of the informal nature of such spaces, despite their cross-border nature. However, a focus on informal political space as a means for (albeit informal) political participation and feelings of empowerment may nonetheless be useful as it allows an exploration into the role that such non-state political space plays. A focus on stateless Palestinians in particular pays testimony to the role that the state and citizenship also play in formal political participation but also the ways in which non-citizens feel politically empowered outside the realm of formal state politics and adapt to having informal political voices with which to advocate causes or issues that are important to them.

There are many problems associated with notions such as participation and empowerment, particularly when the political spaces involved are informal. As Mercer (2002: 102) points out in relation to women and development, "Can one assume that participation is empowering? Moreover, who defines empowerment, and how should it be measured?" In addition, one could also ask why people participate in such spaces in the first place and whether such spaces are felt to be inclusive, exclusive and representative. These are all key questions related to the understanding and relevance of informal political space that are difficult to answer, but which this case study on Palestinians in diaspora in Athens attempts to engage with.

\section{Palestinians in Diaspora}

Palestinians have been living in diaspora since 1948 or what they call the year of the nakba (or catastrophe) and the creation of the state of Israel. They are dispersed mainly throughout the Middle East but also the rest of the world. According to Lindholm Schulz (2003: 45, 74), there are roughly 7.9 million Palestinians in the West Bank, Gaza and the diaspora; there are 1.46 living in the West Bank/Gaza, 4.5 million in diaspora and 1.2 million residing in Israel with Israeli citizenship. Shiblak (2005) estimates that there are roughly 191,000 Palestinians living in Europe, although he also points out that such numbers are difficult to verify as Palestinians are statistically invisible. It seems that Palestinians started migrating to Europe in large numbers from the late 1960s onwards. It 
was only as a consequence (both directly and indirectly) of the 1967 Israeli occupation, the ensuing political turbulence and resistance, as well as the escalating discrimination towards Palestinians in some Arab countries that more large-scale migration to Europe began.

According to the Palestinian Representation in Athens, there are roughly 4000 Palestinians living in Greece. They range from students, to professionals such as doctors and engineers and workers, both skilled and unskilled. The professionals can be split into two groups. There are those who work for foreign companies and who may be in Greece on a more transient basis and often come with their families and those who came to study in Greece, got married (often to Greek women) and settled in Greece (for more on the different Palestinian 'groups' in Greece, see Shawa 2005). Most are first generation migrants in the sense that they made the move to Greece and the majority of participants spoken to started arriving from the 1980s onwards. The research this paper is based on was conducted in 2003-2004 and involved the conduct of fifty-three in-depth and loosely structured interviews with a cross-section of mainly first generation Palestinians in Athens, whose age ranged from 17-60; most, however, were between 20 and 40. Of these, thirty three were men and twenty were women. Interviews were conducted with Palestinians of differing socio-economic status from all 'groups': students, professionals (those working for foreign companies and not), skilled and unskilled workers as well as the unemployed. Forty-eight respondents were Muslim and five were Christian. It is difficult to say if this is representative of Palestinians in Greece as there are official numbers on this. The research also included a series of more ethnographic encounters with some participants, which involved meeting on numerous occasions and repeated attendance at demonstrations, political and cultural meetings and the Parikia. Discussions were held at locations that were easiest for participants; most were conducted in people's homes or places of work.

It has been said that the Palestinian 'name' and national identity was born in 'exile' (Turki, 1994: 160; Said 1990: 360) and the role that the Palestinian diaspora as well as the Palestinian Liberation Organisation (PLO) has played in helping to advocate what many Palestinians call the 'Palestinian cause' or 'struggle' has also been documented (Lindholm Schulz 2003). The cause can be outlined as the seeking of 
freedom for Palestinians, an independent state, an end to Israeli occupation and a just solution for Palestinian refugees as well as Jerusalem. Drawing on research on Palestinians in Sydney, Cox and Connell (2003: 337) have pointed out that a political agenda is very important to Palestinians in diaspora: "the agenda is ultimately designed to reinforce the possibility of a Palestinian homeland, and to maintain the perpetuation of a Palestinian identity, in a world that has largely denied this".

Palestinians in diaspora may be seen as part of a diasporic or transnational community engaged in the process of 'long-distance nationalism' (Glick Schiller and Fouron, 2001; Skrbis 1999), 'nation-state building' or 'homeland-orientated politics' (Lindholm Schulz 2003) that is the result of cross-border connections with the homeland. However, there are also disagreements as to whether all Palestinians in diaspora feel connected to the homeland (for example, see Hanafi (2005) on connections between European and North American Palestinians and the homeland) and whether, therefore, they feel politicised enough to take part in advocacy of the cause. For many in Europe, disillusionment and apathy has apparently resulted in the loss of a coherent and collective cultural identity, making them feel confused about where they perceive they belong and where their home is (Shiblak 2000). In Sweden, for instance, Ghani (2000) describes how Palestinians live on the periphery of Swedish society in a state of alienation, finding little comfort in knowing that they are Palestinian and that they have a homeland.

The situation is different in Greece. Cox and Connell (2003: 334) have pointed out that "Palestinians in the diaspora are...primarily a political construction". The research this paper is based on has found that many respondents are politicised, have a strong sense of being Palestinian and of belonging to a Palestinian homeland. Therefore, it is important to note the close connections between political and cultural identities in the case of Palestinians in Athens. Many respondents are keen to advocate the Palestinian cause in whatever way possible and to whoever will listen. They get involved in advocacy because they feel Palestinian and want to promote Palestinian issues to a wider audience and especially Greeks, who appear to be, on the whole, supportive of Palestinians. This support, together with the geographical proximity between Greece and the Middle East makes Greece an interesting and useful location to study. In addition, the fact that many Palestinians are not Greek or Palestinian citizens, (because Greek 
citizenship is closely protected and Palestine is not yet an official state) and, therefore, have no formal political voice in Greece or Palestine means that despite the potential for cross-border connections, formal political participation is often impossible.

Palestinians in Athens, like many other Palestinians in diaspora without the citizenship of the country in which they reside are in political limbo, without any formal political rights. They feel that a major problem facing Palestinians 'outside' (Palestine) is the paucity of a political voice with which to be heard, a lack of political participation and therefore, the lack of formal ways to have their plight heard by governments. Despite this, Lindholm Schulz (2003) points to the increase of spaces and events such as demonstrations in different European countries that allow Palestinians to advocate the cause and voice their dissatisfactions and hopes. Shawa (2005: 134) has also commented that, for Palestinians in Greece, informal networks have an important role to play. However, it is necessary to move beyond such statements to examine the intricate nature of such spaces in relation to feelings of empowerment and inclusion.

\section{Demonstrations}

This research found that many Palestinians in Athens are involved in demonstrations, either regularly or on an occasional basis. These informal diasporic political spaces are set up and organised occasionally, when it is felt they are needed. Although grounded in Greece, they are cross-border in nature as they cannot be separated from the ongoing political and humanitarian situation in Palestine and the Middle East and the intense feelings of being part of a troubled Palestinian homeland. Respondents who become involved in demonstrations describe feelings of pride at being Palestinian, their happiness at holding up their flag and banners and their ability to shout for justice (and have an informal political voice) when they go. Demonstrations are spaces in which Palestinians (and Greeks) can walk together creating and representing images of unity and solidarity, showing their support for the Palestinian cause. Demonstrations in support of Palestinian issues are important for Greeks as well as Palestinians as political relations have generally been good between Greeks and Palestinians (Shawa 2005: 135).

For many respondents, being in Greece away from Palestine and the Middle East has led them to feel 'free' to express themselves and have a voice that can be potentially 
heard by others, be they other Palestinians, Greeks or the international community. Demonstrations also form informal, visible and material symbols of discontent, perhaps reminiscent of Tarrow's (1998) 'contentious politics'. At the same time, however, those who attend help define what it means to be Palestinian in diaspora; invariably this results in politicised identities and the need to advocate the Palestinian cause, which in turn can foster feelings of empowerment and hope for future change.

The educating of others (and Greeks in particular) about Palestinian issues and perceptions of injustice and discrimination is seen as one of the major (and few) ways many respondents feel they can help fellow Palestinians and promote change in Palestine. As Cox and Connell (2003: 336) stress: "integral to the Palestinian experience of exile throughout the world has been an incessant need to reaffirm history and background". Demonstrations are seen as an important way to help achieve this and, in the process, are spaces in which identity and politics merge. The following two quotes are illustrative:

I think it's very important for Palestinians to spread the word, to give the other side, our side of the story. I mean the people here in Europe are influenced by Jewish people and the media, they don't tell both sides of the story and this is our role, to try and get people to listen to our story, so it's very important and it's part of the struggle. (Maha, housewife)

$\operatorname{xxx}$

Bilal: I've been to every one [demonstration] - it's like my duty.

L: How do you feel when you go? Do you feel that you're making a difference?

Bilal: We are trying to say what we need to say, to show that I am not happy with the situation. I am expressing myself and I am showing my support. If there are any changes, we will be the ones to make or to force that change, not America or somebody else; we have to be in charge of our own future. (Bilal, Foreign Company Employee, FCE hereafter) 
Bilal also stresses the issue of informal representation and freedom of expression. By going to demonstrations, many respondents feel they are more 'in control', representing themselves and their political opinions as well as actively trying to get their messages of advocacy across to a wider audience as a collective. In the process, this may make them feel more empowered. As Bilal re-iterates: "One person on his own cannot do anything; if we are a group then we can do something and I believe in the media a lot in order to publicise your case to the people and to let people know". The ability to come together within such defined spaces may surpass individual feelings of despair and disillusionment felt at other times and spaces because they are expressing not only their unity but also their identity and political commitment to a Palestinian homeland and future state. Such spaces, therefore, have an integral role to play in constructions of dynamic Palestinian identities-in-the making.

For example, Dina, a teenager, describes her emotions as she attends demonstrations. Her active negotiation and embodiment of what it means to be Palestinian as an individual and as part of a group at particular moments in time and space are evident:

When I go, I don't feel like the person I am normally, who lives in Greece. We were there, in the centre of it and most were men, they were carrying dummies of Bush and Sharon. There wasn't anything violent. They were ripping up the doll and I did too. Suddenly, I started to feel this rage. It suddenly hit. I really felt I related; I felt so Palestinian at that point. That was so me; this is me. It didn't feel wrong. It's a rage that every single Palestinian feels.

Here, the personal implications of attending such spaces can be seen. Although she may not describe the process as 'empowering' per se, the powerful feelings of solidarity and affinity with fellow Palestinians that have translated into her wanting to help and be involved in the Palestinian cause in the future may be seen as making or trying to make a difference. The role such diasporic spaces have in helping trigger shared feelings of suffering and injustice but also of belonging, politicisation and the propensity to continue 
advocating is clear. Space has become appropriated, used and malleable. As agents engaged in potential political change through advocacy, people can affect spaces. They can feel altered, empowered (or disillusioned) by the experience and manipulation of space.

Diasporic spaces such as demonstrations are dynamic and contested because respondents invest in them and use them differently over time and space depending on changing factors such as financial/social circumstances, availability of resources, feelings of (in)security, in/exclusion and attachment to the cause and homeland. In turn, this can affect perceptions of the value and relevance of involvement (and indirectly, feelings of empowerment) in such spaces. As Stone (2002: 8) claims, "participation is often voluntary, but only to those with the means or resources". For example, although Maha (housewife) feels that demonstrations are important, she also points to surveillance as a problematic barrier to involvement:

There is so much to do [in daily life], you don't have time. The only thing is demonstrations - we can't do anything else. There is nowhere we can go and give our vote, we have no voice and we can't do anything also because the intelligence in Europe, in the US, in the Middle East, it's all connected with each other, so everyone is scared from everyone outside. If a Palestinian wants to say something [in Greece] or do something and go back home, his name will be on the borders, he did this, he did that and this will make things difficult for him there.

Issues of oppression are often hidden factors that prevent inclusion in such spaces and they strongly suggest the role of power relations and networks that follow people across borders and may be difficult to overcome, despite their supposed freedom in diaspora. The theoretical 'open-ness' of political space that can constitute 'the political' (see Dikeç, 2005, citing Nancy 1988; 1991) may be present. However, the specific factors that prevent or encourage informal, non-state participation need to be examined, for without the formal capacity of the state to help ensure representation, democracy and so forth, such spaces are even more dependent on 'open-ness', accountability and accessibility. It is perhaps not hard to see why negative experiences of 'the political' within such spaces 
would harbour and encourage perceptions of these spaces as apolitical. After all, these spaces are not necessarily open and inclusive to all Palestinians and because they are not formal, they are not seen as overly political. Therefore, it is unsurprising that many respondents seem to associate political activities with formal political spaces, which most have no access to. As a result, demonstrations, as informal spaces and processes may seem different to 'proper' democratic politics carried out in 'proper' formal spaces by citizens and may help explain why demonstrations are not necessarily always seen as political spaces and, therefore, as not particularly empowering. As a young student recently arrived from Jordan with few material connections to Palestine, Karim says he feels unable to help fellow Palestinians and get involved in political activities despite the fact that he attends demonstrations. At the same time, he is aware of potential future changes to his situation which may affect his propensity to get involved in political spaces and activities, highlighting the dynamic nature of politicisation within such spaces:

I can't do anything to help the situation there. Every beginning is difficult and I am still at the beginning so there is nothing I can do to help. Later on, I will do more. I want to go there, to help, to do whatever I can, but the future is uncertain. Nobody knows what will happen there and nobody knows what the future will be so I don't what I will do or what I will be able to do to help.

L: Do you feel hopeless living here, that you're not able to do anything to help?

Karim: Yes, I do feel that I can't say or do much. I talk about things to my friends and we discuss what we see, what's happening, but what can we really do? Okay, we go to demonstrations. We can only talk and discuss our cause. I suppose the only things we can do is tell people what has happened to us to show the world what what's really going on there. We cannot get involved in politics here like the Greeks. But I have to do what I can. 
Despite the fact that he goes to demonstrations, talks to Greeks and tries to 'educate' them, Karim still feels hopeless because he does not view the informal spaces and activities he is involved in as politically useful. He views demonstrations as positive spaces he is able to attend when he has the time to do so, but is ambivalent over their value and political significance, which is related to the fact that he is a non-citizen and that such spaces are not part of the formal political sphere accessible only to citizens.

Similarly, although Samira (housewife/artist) claims she is not political, she emphasizes that she and her husband Mourid, a FCE "always go to demonstrations". Such a division between what is deemed political (and linked to the formal sphere) and actions that advocate the cause (in informal spaces) seem representative of many respondents. As a result, they tend not to see the actions they are involved in as political even though they feel politicised. This can result in them feeling apathetic or disillusioned about what they are actually doing or feel able to do, despite their politicisation and advocacy. Therefore, although such spaces may be connected to Palestine and the situation there, their unbounded nature does not necessarily mean that respondents feel that they are able to create change 'there' by being involved in them 'here'. For example, Ibrahim (construction worker) feels that concrete cross-border networks and actions such as the giving of money are more useful ways to effect change and it is these he finds empowering, not demonstrations:

I don't really believe that much in demonstrations although I have taken part in a few that have led to the Israeli embassy but it doesn't do anything. The struggle, for me is when you give 50 euros to a struggling family in Palestine so that they can live for 10 days and resist for longer. This actually helps people. Just saying I'm on your side, that doesn't do anything.

The value of attending demonstrations may be constructed as positive or negative; however, involvement in such spaces may also result in ambivalence, often fuelled by feelings of guilt and detachment from the homeland. Therefore, although these spaces may initially appear to be momentarily empowering, they can also become a reminder of a homeland that has been lost, of the seemingly endless conflict in Israel/Palestine, of 
identities and histories under threat and of the inability to physically be 'there' and effect change from within. Mahmud's testimony is indicative:

There are moments when you see the situation getting worse there, you leave your work and things and university and you sit and concentrate on that. With the problems in Bethlehem, when they went into the Church of the Nativity and with Arafat, we sat and stayed outside the Israeli embassy. [We set up] this stage, or demonstration, as students....from the moment that these scandals happened, we left everything and we sat outside the Israeli embassy for 24 hours in the cold and the most important thing is that we didn't stop thinking that we were going through nothing compared to what the people there were going through and then I have to say then you feel tortured and you fight with yourself, look I am here and I'm okay, I have a job and I'm lucky.

L: Do you feel that you're doing enough to help?

Mahmud: I try, I try to do whatever I can to help but despite all that I do, I am only doing $1 \%$ of what I could be doing - you can always do more...these things are good and right and we have to do them because you give the right information about Palestine to people but a person who is there like my fellow students there, picks up rocks, weapons, whatever he can and he goes and he fights... when I go to a demonstration, talk on television or whatever, nothing happens to me, and you become very affected and you start thinking about things and about what you're doing here. You feel that you don't belong here. So there is always this battle going on inside you. It's just that everyday life and stuff, you have to focus on that and get on with it... and for seconds sometimes you forget the situation there.

Mahmud, a student, exemplifies the very real tensions and guilt many respondents experience in their everyday life as a result of their cross-border connections and existence. These may spur them to get involved politically but also depresses and upsets them because they feel that they are not doing enough and not suffering in the same way 
as fellow Palestinians in the West Bank and Gaza and in refugee camps throughout the Middle East. However, they may be doing all they feel they can, given their situation. This does not necessarily stop them from feeling guilty and helpless at times. Resonating with Mercer's (2002) findings in Tanzania on why women (and men) participate, Mahmud appears to have an individual reasons explaining his choice to advocate, which is linked to particular events and times that made him start thinking about getting involved but he also illustrates that such participation is complex and dynamic over time and space.

For some respondents, statelessness and exile has meant that going to demonstrations is often an important part of diasporic life. Such political spaces may be useful to them as they experience and practice their identities and feelings of politicisation and political commitment to the Palestinian cause and unity by attending. However, many Palestinians also seem to be ambivalent about the nature and importance of these spaces, particularly when it comes to defining them as political, useful or inclusive and there is no consensus on whether demonstrations are empowering. The discussion on the Parikia below sheds further light on such issues.

\section{The Parikia}

The Parikia (in Greek, Jalia in Arabic), or community house, is an informal diasporic space that was conceived by its founders as being a Palestinian, as well as Arabic space and therefore, plays an important role in Palestinian constructions of identity and belonging. It allows those involved to socialise and interact with other Palestinians within a Palestinian (and Arabic) environment. However, it can also be seen as a political space integral to the advocacy of the Palestinian cause helping make Palestinians feel politicised, construct notions of unity, 'shared consciousness' or 'imagined communities' (Anderson 1983) and solidify their feelings of being symbolic connection to their homeland.

Palestinians who attend the Parikia play a role in organising and publicising activities and events associated with the Parikia, such as demonstrations, cultural and charity events, which are in turn connected to local Greek NGOs as well as Greek, and Palestinian Unions, whose members may occasionally also be present. Meetings take 
place most Saturday afternoons/evenings and appear to be open events in which people (Palestinians and non-Palestinians) are free to walk in and out. Events are also organised there, such as barbecues, speeches and charity events but above all, it remains an informal space that operates outside the realm of Greek (and Palestinian) politics. However, despite the potentially inclusive nature of the Parikia, there are Palestinians who do not attend. Many respondents see lack of time as a major restriction to going there and only those who are extremely committed appear to find the time to attend and get involved on more than a superficial basis. As Lina (businesswoman) points out: "People here try but the thing is, a big percentage of Palestinians, their first worry is to work and support their family, which is maybe why not everyone can participate". This is a reminder that going to such informal spaces is voluntary and has to be fitted into and forms part of daily life and survival. As a result, such spaces are not necessarily seen as inclusive as those who are less able to go because of family or job commitments may feel excluded.

In addition, the informal nature of the Parikia also attracts criticism and has stopped people from attending. This is often linked to the perception that it is not a political space and that not enough politically useful activities are carried out there. Therefore, as a space within which people can feel empowered, it is limited for some respondents. Rania, (FCE) for example, feels that the Parikia is just about: "gossip, I don't like it. No actions are done. We have to be active, they, there have to be more active...events to help [fellow Palestinians] should take place every week." This highlights that Rania feels that such diasporic spaces need to be infused with political meaning and intent. Having such a space in itself is simply not enough in her view and as a result, she does not go because she does not have to. By choosing not to participate, she is excluded in the process, as are numerous others who share her views. Layla (FCE) also describes her own similar feelings:

These people go there just to meet socially, they celebrate things sometimes for Palestine, or they have people from Palestine talking. But I'm very busy, so I can't just go any time they say they are having something, but I would find the time to go if I thought that what they were doing was really useful. It's just only 
talking...Things should be more organised and what they are doing should be directed to the Europeans. We have to tell the Europeans, come and see the truth because Israelis they are really better than us in this... But we Arabs are so lazy. Also, we are not supported by the Arabs. Unfortunately, not the government or the people are supporting us - it's just words. They say we love Palestine and the Palestinians and we do whatever they want but nothing happens. And it's not only that - me...I can't go anywhere in the Arab world. We have to have good media, a schedule, a plan, to tell the Greeks the truth, what's really going on. [At the Parikia] they need to do things to help the Palestinians, at least the ones who are here. I need something stronger to be done, to help me practically. Something to change my life.

Layla's focus on the need for the Parikia to provide help to Palestinians is Athens is interesting and unusual. She highlights her perceptions of the Parikia as inadequate and her own visions of what Palestinian diasporic politics should entail. At the same time, it cannot be assumed that lack of physical participation in particular spaces means a lack of advocacy or politicisation, as respondents may advocate in other spaces such as the home or at work. For example, Rania feels she is 'helping' the Palestinian cause by not buying Israeli products and encouraging her Greek friends to do the same but does not feel that this is enough. For Layla, Rania, and those with similar views, being politicised constitutes a proactive, organised commitment within spaces that can respond to their demands and needs. They may have ideas on how to change things and make advocacy processes more effective but because they are excluded, their voices will most likely not be heard. Above all, they do not associate the Parikia with empowerment or political change. As a space that was intended to bring Palestinians together, the Parikia has, for some, had the opposite effect and because it is an informal space, there are no official, formal ways to help ensure inclusion, or representation, an issue many respondents find important.

In the case of the Parikia and other diasporic spaces, the importance of the issue of representation is highlighted by feelings of inclusion and exclusion that occur within and as a result of such spaces. These feelings are often the result of perceptions of whether they are being fairly or inadequately represented by such spaces and the people 
within them. Unsurprisingly, there are those who feel that the Parikia does not represent them and as a result they may feel excluded from attending, or if they do, they may feel uncomfortable or restricted in terms of discussions and potential actions. As Ibrahim (construction worker) explains:

We do go, but I personally don't like it very much because those who have set it up don't represent those Palestinians who are living this nightmare. They only set it up just for the image, just for people to see them doing something but they don't have anything to do with those who are involved in the struggle, so they are not really involved in or doing anything about it to help. And the leader is a very rich Palestinian, okay he does care I suppose. I've been there a few times. I like being with Palestinians. [But] they don't do many things... Most of the people who go have more money and do whatever they want so it doesn't make any difference if poorer people go. It represents certain people, a certain category of people, not everyone.

Ibrahim and other respondents suggest that money has a role to play in who goes there; consequently, it may be seen as elitist and prone to the negative effects of power relations and inequalities. As Thrift (2000: 274) notes, "space...is the stuff of power". The networks, which help make up these spaces, may be controlled by elites (Stone 2002, citing Jacobson 1995), gate-keeping, patronage and the dominance of certain (elite) interests, which are problematic for other members. As Featherstone (2003: 408) stresses: "attention needs to be directed to the [multiple] ways in which political activity both negotiates and creates cross-cutting relations of power". This is particularly important when those involved are stateless and/or non-citizens in the society in which they live, as there are often no formal means to deal with power inequalities and disagreements with those in positions of power.

Diasporic spaces such the Parikia, although theoretically open and inclusive, are at the same time, contested as well as closed and exclusive. In the process, a form of 'double exclusion' may be emerging, whereby respondents feel excluded not only from Greek and Palestinian formal political sphere but also within diasporic political spaces. 
Visible spaces, such as the Parikia and demonstrations that are supposedly open to all Palestinians in Athens have the potential to constitute a site for 'action' and 'engagement' (see Cornwall 2002) needed to encourage feelings of empowerment and lessen feelings of apathy and despair. Such political spaces will never be without contestation and disagreement. As mediated, subjective and dynamic spaces, they are given constant changing meanings by those involved. Theoretically, at least, for those who are involved, there is always the capacity for perceptions of empowerment through discussion and negotiation, however 'messy', chaotic and tense this may be in the process. As Jamal (FCE) stresses: "these spaces are a start at least, they are better than nothing, somewhere to speak out and have our voices heard". It may be said that, for Palestinians in diaspora, "thought needs to be given to the political deployment of (real, imagined, symbolic) space and the purpose of such questioning is to enable the formation and maintenance of progressive political alliances" (Keith and Pile, 1993: 36), as well as hope.

\section{Conclusions}

This paper has problematised notions of empowerment through its focus on informal diasporic political spaces in Athens. It has shown that there are differing participant responses to such spaces and that those involved may feel both empowered and disempowered in the process. Therefore, it adds to research on transnational and diasporic politics by highlighting the important role that citizenship and formal legal status plays as it has shown that those without citizenship may struggle to participate politically despite the informal political spaces they may be involved in. In addition, the paper has illustrated that despite the fact that such spaces are diasporic in nature and are affected by cross-border connections, the propensity for cross-border or transnational political action may be limited for those without citizenship and that they may not feel that the 'contentious politics' (Tarrow, 1998) they may be involved in is useful or effective in creating political change in the homeland. At the same time, it has noted that the presence of such spaces can potentially be positive for migrants and those in diaspora without citizenship and a starting point for collective feelings of politicisation, political advocacy, communication and political change in relation to identity. 
The paper has shown that political spaces within which Palestinians in Athens are involved are complex as well as contested and can be perceived in a positive and negative light. On the one hand, one can view such political diasporic spaces and practices as creative ways to deal with informal status and the paucity of political representation, to increase dialogue, feelings of agency, empowerment, freedom and so forth. Given the type of specific homeland-orientated advocacy many Palestinians want to pursue on a personal level, they may feel that such diasporic political spaces are good ways to participate when and if they can, despite the problems and limitations involved in doing so. Despite the limitations of physical and formal political involvement in Palestinian or Greek politics, such informal diasporic spaces tangibly bring together Greece, Palestine and the wider Middle East forcing an initial process of communication and dialogue within what is a diverse diaspora and the starting point for (albeit contested) negotiations of identities, politics and in/exclusion as well as ways to create change. One may, therefore, surmise that spaces in which such politicisation and potential empowerment may take place are important despite the fact that they are informal. On the other hand, such spaces and practices are not necessarily representative or inclusive for all members of the diaspora. They may not find them particularly empowering and, as they are beyond the control of the state, not only may it be difficult to ensure that they are, but also, their value as a legitimate space for politics, often decreases.

This paper suggests that respondents often appear to feel both empowered and disillusioned by the diasporic political spaces they are involved in and consequently they are difficult to generalise about. Many appear to oscillate between feelings of hope, resistance, apathy and despair as a result of attendance at the Parikia and demonstrations. Therefore, they may for example, talk of the importance of remaining united, of loving Palestine, of hope for the future and belief in the cause. At the same time, they also talk of feelings of helplessness, suffering and apathy due to their citizenship status, economic positions, their physical separation from and the ongoing issues 'there'. Narratives and discourses of diasporic solidarity and politics need to take into account the fact that such processes are often problematic for those involved. Instead of simplistic analyses of such politics, which on the surface, may appear successful and empowering for those involved, a more in-depth look reveals the tensions and struggles involved as power relations, 
exclusions, politics and identities are played out across spaces that are transgressive and open-ended as well as potentially inward-looking, restrictive and bounded. At the same time, this paper has demonstrated the value of examining informal political spaces, which may be seen as important aspects of diasporic politicisation and constructions of identities, particularly for those who are non-citizens and/or stateless.

Although politics is increasingly being seen as transnational and cross-border in nature, this paper has also highlighted that although there may be networks between host/homeland societies, politicisation may often be limited to more localised informal diasporic spaces, which despite being connected to the homeland are physically grounded in the host country. The lack of formality surrounding such advocacy may also prevent any grievances from being heard and acted upon and from ensuring that such spaces are inclusive and representative and do not necessarily trigger or inspire collaboration and communication within the diaspora but also in relation to others in the host/homeland society. In the meantime, countless Palestinians in diaspora with and without host country citizenship live 'in limbo' in terms of their political representation in Palestine. Despite the attempts of a great deal of homeland-orientated advocacy throughout the diaspora via diasporic spaces and networks, both material and virtual, and the acceptance of the important role that diasporic Palestinians play in advocating the cause, a solution to the Palestinian-Israeli conflict is not yet in sight. This may lead us to question just how effective informal political space is in creating physical changes in the homeland/country of origin. Despite the effectiveness with which Palestinians 'cross borders' symbolically, they still associate political participation with formal political spaces, which they themselves often lack access to, highlighting the material importance of the state in the processes of empowerment and the creation of political change for non-citizens and those who are stateless.

\section{Acknowledgements}

I am grateful to the Economic and Social Research Council (ESRC), who funded the research this paper is based on (PTA 030-2002-00600). I would also like to thank Cheryl McEwan for her support and guidance. 


\section{References}

Adamson, F. (2002) Mobilizing for the transformation of home: politicized identities and transnational practices. In New approaches to migration? Transnational Communities and the transformation of home ed., N. Al-Ali and K. Koser pp. 155-168. Routledge, London.

Al-Ali, N. (2002) Trans- or a-nation?: Bosnian refugees in the UK and the Netherlands. In New approaches to migration? Transnational communities and the transformation of home ed., N. Al-Ali and K. Koser pp 96-117. Routledge, London.

Al-Ali, N., Black, R and Koser, K. (2001) The limits to 'transnationalism': Bosnian and Eritrean refugees in Europe as emerging transnational communities. Ethnic and Racial Studies 24 (4), 578-600.

Anderson, B. (1983) Imagined communities. Verso, London.

Basch, L., Glick Schiller, N. and Szanton-Blanc, C. (1994) Nations unbound: Transnational projects, postcolonial predicaments and deterritorialised nation-states. Gordon and Breach, Amsterdam.

Benhabib, S. (2004) The rights of others: Aliens, residents and citizens. Cambridge University Press, Cambridge.

Brah, A. (1996) Cartographies of diaspora. Routledge, London.

Carter, S. (2005) The geopolitics of diaspora. Area 37 (1), 54-63.

Castles, S. and Davidson, A. (2000) Citizenship and migration: Globalization and the politics of belonging. Macmillan, Basingstoke. 
Cornwall, A. (2002) Making spaces, changing places: situating participation in development. IDS Working Paper 170. IDS, University of Sussex.

Cox, J. and Connell, J. (2003) Place, exile and identity: The contemporary experience of Palestinians in Sydney. Australian Geographer 34 (3), 329-343.

Croucher, S. L. (2004) Globalization and belonging: The politics of identity in a changing world. Rowman and Littlefield, Maryland.

Cunningham, H. (2001) Transnational politics at the edges of sovereignty: Social movements, crossings and the state at the US-Mexico border. Global Networks 1 (4), 369-387.

Danese, G. (1998) Transnational collective action in Europe: The case of migrants in Italy and Spain. Journal of Ethnic and Migration Studies 24 (4), 715-733.

Dikeç, M. (2005) Space, politics and the political. Environment and Planning D: Society and Space 23, 171-188.

Faist, T. (2000) Transnationalization in international migration: Implications for the study of citizenship and culture. Ethnic and Racial Studies (23) 189-222.

Featherstone, D. (2003) Spatialities of transnational resistance to globalization: The maps of grievance of the Inter-Continental Caravan. Trans Inst Br Geogr. 28 (4), 404-422.

Flint, C. (2002) Political geography: globalization, metapolitical geographies and everyday life. Progress in Human Geography, 26 (3), 391-400.

Geddes, A. (2001) International migration and state sovereignty in an integrating Europe. International Migration 39 (6), 21-40. 
Ghani, D. A. (2000) The Palestinian community in Sweden. Paper given at a conference on Palestinian Refugee Communities in Europe, St Anthony's College, Oxford, in association with the Refugee Studies Centre, Shaml (The Palestinian Diaspora and Refugee Centre), May.

Glick Schiller, N. and Fouron, G. (2001) Georges woke up laughing: Long distance nationalism and the search for home. Duke University Press, Durham and London.

Guarnizo, L.E. and Smith, M.P. (Eds. 1998) Transnationalism from below. New Transaction Publishers, Brunswick.

Hanafi, S. (2005) Reshaping geography: Palestinian community networks in Europe and the new media. Journal of Ethnic and Migration Studies 31 (3), 581-598.

Itzigsohn, J. (2000) Immigration and the boundaries of citizenship: The institutions of immigrants' political transnationalism, International Migration Review 34 (4), 11261154.

Keith, M. and Pile, S. (Eds. 1993) Place and the politics of identity. Routledge, London.

Kofman, E. (1995) Citizenship for some but not for others: Spaces of citizenship in contemporary Europe. Political Geography 14, 121-137.

Leibowitz, D. (2002) Gendering (trans)national advocacy: Tracking the Lollapalooza at 'home'. International Feminist Journal of Politics 4 (2), 173-196.

Lindholm Schulz, H. (2003) The Palestinian diaspora: Formation of identities and politics of homeland. Routledge, London.

Lipschutz, R. (1992) Reconstructing world politics: the emergence of global civil society. Millennium, 21 (3), 389-421. 
Marden, P. (1997) Geographies of dissent: Globalisation, identity and the nation. Political Geography 16 (1) 37-64.

Massey, D. (1999) Spaces of politics. In Human Geography Today ed., D. Massey, J. Allen and P. Sarre, pp. 279-294. Polity Press, Cambridge.

McEwan, C. (2004) Travel and transnational spaces. In Companion to Cultural Geography ed., N.C. Johnson, R. Schein and J. Duncan. Blackwell, Oxford.

Mercer, C. (2002) The discourse of Maendeleo and the politics of women's participation on Mount Kilimanjaro. Development and Change 33, 101-127.

Mitchell, K. (1997) Transnational discourse: Bringing geography back in. Antipode 29 (2), 101-114.

Nash, C. (2002) Cultural geography: Postcolonial cultural geographies. Progress in Human Geography 26(2), 219-230.

Nagel, C. and Staeheli, L. (2004) Citizenship, identity and transnational migration: Arab immigrants to the United States. Space and Polity 8 (1), 3-23.

Ong, A. (1999) Flexible citizenship: The cultural logics of transnationality. Duke University Press, London and Durham.

Østergaard-Nielsen, E. (2001). The politics of migrants' transnational political practices, ESRC Transnational Communities Working Paper WPTC-01-22. http://www.transcomm.ox.ac.uk. 
Østergaard-Nielsen, E. (2003) The democratic deficit of diaspora politics: Turkish Cypriots in Britain and the Cyprus issue. Journal of Ethnic and Migration Studies 29 (4), 683-700.

Said, E. (1990) Reflections on exile. In Out there, marginalization and contemporary cultures ed., R. Ferguson, M. Gever, T. Minh-ha and C. West, pp. 357-366. MIT Press, Cambridge.

Shawa, S. (2005) Palestinians in Greece: same sense of belonging, diverse communities. In The Palestinian diaspora in Europe: challenges of dual identity and adaptation ed., A. Shiblak. Shaml (The Palestinian Refugee and Diaspora Centre) and the Institute of Jerusalem Studies. Available online at http://www.rsc.ox.ac.uk/PDFs/Shiblak.pdf

Shiblak, A. (2005) Reflections on the Palestinian diaspora in Europe In The Palestinian diaspora in Europe: challenges of dual identity and adaptation ed., A. Shiblak. Shaml (The Palestinian Refugee and Diaspora Centre) and the Institute of Jerusalem Studies. Available online at http://www.rsc.ox.ac.uk/PDFs/Shiblak.pdf

Shiblak, A. (2000) Palestinian refugee communities in Europe: an overview. Paper given at a conference on Palestinian Refugee Communities in Europe, May, St Anthony's College, Oxford, in association with the Refugee Studies Centre, Shaml (The Palestinian Refugee and Diaspora Centre).

Skrbis, Z. (1999) Long-distance nationalism: Diasporas, homelands and identities. Ashgate Publishing, Aldershot.

Smith, M.P. and Bakker, M. (2005) The transnational politics of the Tomato King: meaning and impact. Global Networks 5 (2), 126-146.

Soysal. Y. (2000) Citizenship and identity: living in diasporas in Post-War Europe. Ethnic and Racial Studies 23 (1) 1-15. 
Soysal, Y. (1998) Towards a postnational model of membership. In The Citizenship Debates: A Reader ed., G. Shafir pp 189-221. University of Minnesota Press, Minneapolis.

Staeheli, L., Ledwith, V., Ormond, M., Reed, K., Sumpter, A. \& Trudeau, D. (2003) (2003) Immigration, the internet, and spaces of politics. Political Geography 21, 9891012.

Staudt, K. (2002) Transcending nations: cross-border organizing. International Feminist Journal of Politics 4 (2), 197-215.

Stone, D. (2002) Introduction: global knowledge and advocacy networks. Global Networks 2 (1) 1-11.

Tambini, D. (2001) Post-national citizenship. Ethnic and Racial Studies 24 (2) 195-217.

Tarrow, S. (1998) Power in movement: Social movements and contentious politics. Cambridge: Cambridge University Press.

Thrift, N. (2000) Entanglements of power: shadows? In (Eds.) Entanglements of power: Geographies of domination/resistance ed., J. Sharp, P. Routledge, C. Philo and R. Paddison, pp 269-278. Routledge, London.

Tölölyan, K. (1991) The nation-state and its others: In lieu of a preface. Diaspora 1(1) 37.

Turki, F. (1994) Exile's return: The making of a Palestinian American. Free Press, New York. 
Varsanyi, M. (2005) The rise and fall (and rise?) of non-citizen voting: Immigration and the shifting scales of citizenship and suffrage in the United States. Space and Polity, 9 (2), 113-134. 